\title{
Implementation of the Right to Adequate Housing: A Glaring Paradigm of Sri Lanka
}

\author{
Taslima Khanam \\ Lecturer, Department of Law, \\ International Islamic University Chittagong, Bangladesh \\ Email: adv.taslima@gmail.com \\ Anju Man Ara Begum \\ Lecturer, Department of Law, \\ International Islamic University Chittagong, Bangladesh \\ Email:adv.anjum@gmail.com
}

\section{Doi:10.5901/mjss.2013.v4n13p447}

\begin{abstract}
Everyone shares the right to a decent standard of living. Essential to the achievement of this standard and therefore to the fulfillment of human life beyond simple survival is access to adequate housing. The international human rights law has sought to translate this vision of adequate housing into practical legal formulation. This article is intended to find out the justifiability of the right to adequate housing at national and international arena and thus urges for the implementation of the right to adequate housing for upgrading the level of living. Here an effort is made to realize the strategies to implement this right to adequate housing from the experiences of Sri Lankan project of successful implementation of this right as because in many cases, it is necessary for governments to provide physical shelter directly to the people. The writing also recommends the needs of judicial enforcement for ensuring the enjoyment of the right to adequate housing as a link with the express guarantees of other rights.
\end{abstract}

Keywords: Universal Declaration of Human Rights, Implementation of Adequate Housing, Housing Program, Demonstration Project, Sri Lanka.

\section{Introduction}

Housing is the provision of accommodation as understood by the common people. In all countries housing is prominent among the factors affecting the level of living. Because it constitutes the physical environment in which society's basic units the family develops. Housing is defined within the Global Strategy as meaning: adequate privacy, adequate space, adequate security, adequate lighting and ventilation, adequate basic infrastructure and adequate location with regard to work and basic facilities all at a reasonable cost. Without doubt these housing rights standards have become increasingly clarified and solidified over the past half decade. Population growth, migration to urban areas, conflicting needs for existing land, and insufficient financial and natural resources have resulted in widespread homelessness and habitation in inadequate housing. In every country children, men and women sleep on sidewalks, under bridges, in cars, subway stations, and public parks, live in ghettos and slums, or "squat" in buildings other people have abandoned. The United Nations estimates that there are over 100 million homeless people and over 1 billion people worldwide inadequately housed. Although the protection of the right to adequate housing enshrined in the Universal Declaration of Human Rights applies to every state yet housing generally is not high on the list of societal needs and governmental priorities.

\section{Elements of Housing Rights}

We have to know the elements that constitute the human right to housing in order to effective implementation of this right. The Habitant International Coalition, a network of NGOs working on this issue, developed a monitoring tool kit that has identified 14 constituent elements of the human right to housing, derived from international treaty obligations and other commonly accepted norms.

These elements are security of tenure, public goods and services, environmental affordability, habitably, accessibility, location, cultural appropriateness, freedom from dispossession, information, capacity and capacity-building participation and self-expression, resettlement, safe environment, security and privacy. 
The right to adequate housing is founded and recognized under international law. Enunciated under article 25 (1) of the Universal Declaration of Human Rights, the right to adequate housing has been codified in other major international human rights treaties. Articles 11 (1) of the ICESCR provides that "States Parties to the present Covenant recognize the right of everyone to an adequate standard of living for himself and his family, including adequate Housing, and to continue the improvement of living conditions. "

The ICESCR has issued two General Comments clarifying the scope and meaning of the right to housing as enshrined in the Covenant.

\section{Housing and Other Rights}

The indivisibility and interdependence of all human rights find clear expression through the right to housing. The full enjoyment of such rights as the right to human dignity, the principle of non-discrimination, the right to freedom of association of expression such as for tenants and other community based groups, the right to security of person in the case of forced or arbitrary evictions or other forms of harassment and the right not be subjected to arbitrary interference with one's privacy, family, home or correspondence is indispensable for the right to adequate housing to be realized, possessed and maintained by all groups in society.

At the same time, having access to adequate and secured housing substantially strengthen the likelihood of people being able to enjoy certain additional rights. Housing is a foundation from which other legal entitlements can be achieved. For example, the World Health Organization (WHO) has asserted that housing is the single most important environmental factor associated with disease conditions and higher mortality rates.

\section{International Instruments on Housing Rights}

The human right to adequate housing is enshrined in international law. The right to adequate housing can be traced to the Universal Declaration of Human Rights, which was unanimously adopted by the world community in 1948. Since that time, the right to adequate housing has been reaffirmed on numerous occasions and further defined and elaborated.

Several non-binding declarations, resolution and recommendations by the UN and its specialized agencies related to housing as a human right are:

- Declaration on Social Progress and Development (1969), part II, art. 10

- Declaration on the rights of Disabled Persons (1975), art. 9

- Vancouver Declaration on Human Settlements (1976), section III (8)

- International Labor Organization (II.O) Recommendation No, 115 (1961) principle II

- ILO recommendation No. 62 Concerning Older Workers (1980), art 5 (g)

- Declaration on the right to development (1986), art. 8 (1)

- United Nations Sub-Commission on the Prevention of Discrimination and Protection of Minorities resolution 1994 on "Children and the Right to Adequate Housing" adopted 23 August 23, 1994

- United Nations Commission on Human Rights resolution 1993/77 on "Forced evictions" adopted on 10 March 1993

- United Nations Commission on Human settlements resolution 154/6 on" The Human Right to adequate Housing" adopted 5 May 1993

- United Nations General Assembly resolution 42/146 on the "Realization of the Right to adequate Housing" had adopted on 7 December 1987, which "reiterates the need to take, at the national and international levels, measures to promote the right of all persons to an adequate standard of living for themselves and their families, including adequate housing, and calls upon all States and international organizations concerned to pay special attention to realization of the right to adequate housing in carrying out measures to develop national shelter strategies and settlement improvement programs within the framework of the Global Strategy to the Year 2000."

Several regional human rights instruments also guarantee to every individual the right to adequate housing. Under the Charter of the Organization of American States (OAS), articles 31(k). "Member States agree to dedicate every effort to achieve adequate housing for all sectors of the population."

American Declaration of rights and Duties on Man (1948) also concern in housing rights. According to article 8 and Article 23: 
"Every person has the right to fix his residence within the territory of the state of which he is a national, the move about freely within such territory and not to leave it except by his own will."

"Every one has the right to own such property as meets the essential needs of decent living and helps maintaining the dignity of the individual and of the home."

Also article 11 of the additional protocol to the American Convention on human rights in the area of economic, social and cultural rights (1988) provides. "Everyone shall have the right to live in a healthy environment and to have access to basic public services."

The European Social Charter, the European Convention on Human Rights and Fundamental Freedoms, the European Convention on the Legal Status of Migrant Workers, the Resolution on shelter for the Homeless in the European Community, and the Final Act of Helsinki, all contain express provisions and references to the adequate housing. With a view to ensuring the effective exercise of the right to housing Article 31 of the European Convention on Human Rights and Fundamental Freedoms designed the following measures.

I. To promote access to housing of an adequate standard;

II. To prevent and reduce homelessness with a view to its gradual elimination.

III. To make the right of housing accessible to those without adequate resources.

The African Charter on Human and People's Rights makes no specific mention of the right to adequate housing. However, other provisions such as the right to life (art. 4) and the right to physical and mental health (art. 16) arguably provide a basis for the assertion of the right of housing.

\section{Legal Aspects of Enforcing and Implementing Housing Rights}

The housing rights are recognized and reaffirmed in all international and regional covenants is an old story. A teasing question that arises is that of their enforceability in each country. The law may not be perfect instrument for bringing full social justice to the community but here it is on the side of homeless and the inadequately housed. So the fact must be concerned. There may not be in many countries a domestic law providing a specific positive right to adequate housing but equally there would be no specific law prohibiting the state from providing adequate housing to its citizens. The important aspect is that there are obligations on housing presently incorporated in international Law.

The universal conscience was sharpened further when, in the Vienna Declaration and program of action, the World Conference on human right urged Governments to incorporate the standards contained in international human rights instruments in domestic legislation and to strengthen the national structures, institutions and organs of society which play role in promoting and safeguarding human rights. Thus international covenants impose a positive duty and obligation on state to provide the adequate housing.

\section{Problems to Implement}

Although the principle issues of housing rights become more clearly defined and have gained greater acceptance in recent years, there remain substantial problems and misunderstandings surrounding the content and the implication of this right.

- Throughout the world there is an increasing tendency to associate housing build or funded by the State with inadequate living conditions, poor health, crime, violence, hopelessness and general deprivation. Admittedly, many public housing programs have in fact failed to provide adequate housing and in the worst cases have provided the basis for the creation of ghettos and extreme social problems.

- States that have recognized the right to housing in their constitutions often fail to implement these provisions. One of the main obstacles to the global realization of the right to housing is the State's persistence when formulating polices and programs and making budgetary allocations, in considering housing as a basic need, not a right.

- Many States that have not recognized the right in their constitutions but have ratified international legal instruments that explicitly mention the right to housing (the International Covenant on Economic, Social and Cultural Rights has been ratified by 130 countries). Taken together one can assess that a majority of the world's notions do not take the steps needed to effectuate the right to housing. Such an intractable attitude on the part of States remains one of the main barriers to people and communities all across the world achieving the right to housing.

A more accurate analysis, it seems, would be based on the simple consideration that housing needs exceed the 
expenditure capacities of national Governments, and that even when funds are devoted to housing these are often spent to the benefit of already more privileged groups. Public funds for housing and urban development can very easily be used to violate housing rights, particularly when such funds are directed towards the programs of urban renewal and the like, programs which clearly benefit the real estate sector at the expense of other beneficiaries. History has shown that public expenditure by Government on housing is never adequate to fulfill social housing needs, and very few Government have utilized such funds in a manner, which reaches the largest number of people possible.

\section{International Activities for Implementation}

\subsection{United Nations Center on Human Settlements (Habitat)}

During its fourteenth session, the United Nations Commission on Human Settlements (Habitat) (UNCHS) adopted resolution 14/6 of 5 may 1993 on the human right to adequate housing without a vote. The adoption of this resolution constituted a significant development. For the first time, that commission explicitly addressed the Human rights implications of housing. Among other things, in resolution 14/6 it requested the Executive Director of the United Nations Center on Human Settlements (Habitat) to consider how the Center could more effectively promote housing rights throughout the international community, indicating the likelihood of increased UNCHS activity concerning housing rights. Also indicative of the growing importance attached to housing rights by this body, it appears that the right to adequate housing will form a key component in the preparatory process leading to the 1996 Habitat II Conference. In this respect, the Special Reporter would like to suggest several ways in which UNCHS could more intensively embrace the right to housing for the possibilities of greater involvement by UNCHS in the housing rights.

\subsection{Economic Commission for Europe}

Concerning the Economic Commission of Europe's Housing Policy Guidelines, the three following points should be mentioned : (1) the creation of decent housing conditions is a prerequisite to the promotion of human development, to the protection of the family, of children and of equality between sexes; (II) only an efficient market can provide the quantity and quality of dwellings required in order to create and adequate housing of all, the implementation of social policies (mainly in the form of the provision of subsidies) is also required.

\subsection{World Health Organization}

The World Organization (WHO) deals only marginally with housing issues. Its main concern, as far as this matter is concerned, is that the overall environment in which individuals live has a direct impact upon their health. The integrated approach of WHO has been reintegrated is several recommendations and has been further defined a lately. More recently (during the 1990s), the world Health Assembly has urged member States to prevent excessive urban population growth and to strengthen the capacity for healthy urban development (WHA44.27). WHO has also developed a regional approach to this problem and has held meetings and workshops on urban health and upgrading of slum areas in developing countries in order better to take into consideration regional issues. It has also launched National Healthy City Programs in Bangladesh, Brazil and Ghana.

\subsection{International Labor Organization}

Although the International Labor Organization (ILO) has not development legislation related to the right to housing per se, it has enacted recommendations resolutions and conventions that deal with this issue. In 1961, ILO adopted Recommendation No. 115 concerning Worker's Housing and proposed guidelines for legislation and practices countries night wish to adopt. It is one of the most comprehensive legal texts on housing and spells out inter alia objectives of national policy and the respective responsibilities of public authorities and employers in providing worker's housing, inter alia by making available loans at moderate interest rates. It also elaborates housing standards, including space per person or family in terms of floor area, cubic volume and size and number of rooms, the supply of safe water, adequate sewage and garbage disposal appropriate protection against excessive temperature and a minimum degree of privacy. 


\section{Sri Lanka: A Glaring Example of Implementation of Housing Rights}

Soon after the general elections of 1977, the Minister of Local Government, Housing and Construction, Ranasinghe Premadasa, became the Prime Minister, but he continued to retain the Housing portfolio. His election pledge was to build a hundred thousand houses in five year period. Funds amounting to an unprecedented $10 \%$ of the country's GNP were allocated to the housing program in years 1979 to 1980 . This same commitment to the cause of the cause of better housing for the poor was made known to the international community.

Efforts were made to mobilize technical resources. There was clear shift in the political stance in that the private sector, in the form of firms of consultants, contractors, developers and consortia, were seriously encouraged to participate in the government house building program. Work was initiated by the Department of National Housing. Soon thereafter in April 1979, a new agency with wide power, the National Housing Development Authority (NHDA), was established to lead the program, Half of the proposed hundred thousand units were to be built by the aided self-help method in the rural areas. A third of the housing units were to be built in the urban areas by direct construction. These, including some high-rise projects were to be for the middle and upper-middle income groups. The remaining funds were to be allocated to a slum and shanty upgrading program which was implemented mainly in Colombo.

Table 1: Hundred Thousand Houses Program 1979-1983

\begin{tabular}{|l|c|c|c|}
\hline Large neighborhood schemes in hinter-land of Colombo & Urban & Direct construction \\
\hline Slum and Shanty up grading program & Urban & Direct construction \\
\hline Electorate Housing for Poorest of the Poor & Urban \& Rural Aided Self-Help (1981-1983) & $\begin{array}{c}\text { Direct construction } \\
(1978-1980)\end{array}$ & 36,000 \\
\hline Rural Housing & Rural & Aided Self-Help & Rural \\
\hline Village Reawakening & Urban Mainly & Aided Self-Help & 50,000 \\
\hline Housing Loans & & -- & 14,000 \\
\hline Total & & $1,00,000$ \\
\hline
\end{tabular}

Source: Page- 9, Shelter in Sri Lanka, Govt. Publication, 1987

Important features of this housing program were is national scale and its disruptive equity. The urban low income settlements were dealt with by a Division of the Urban Development Authority (UDA). This Slum Shanty Division had been established at the outset in 1978. Activities of this Division, which were again mainly Colombo-based, at a small scale and on a project basis covered the following:

- Permanent upgrading which include improvements to the physical social and economic environment.

- Temporary upgrading where minor improvements were provided.

- Relocation to alternative sites where improved housing was provided along with ancillary facilities and community services.

The UN center for Human Settlements in fulfilling its tasks for the International Year of Shelter for the Homeless (1987) identified a few projects worldwide to be implemented as International 'Demonstration Projects'. These were to test out innovative methodologies in urban low income housing. It is noteworthy that four of these were selected in Sri Lanka and that these were successfully implemented. The projects were:

1. Maligawatte West (inner city slum improvement),

2. Seevelepura (Shanty Upgrading),

3. Navagamura (site and service/re-location) and

4. Malkaduwawa (urban neighborhood upgrading).

The another program is The Million houses Program (1984-1989)

The recognition of this program reflected a new, vigorous and creative trend of thinking within the NDHA and the ministry. The idea was that the government would support a million or families in their efforts to upgrade or build shelter for themselves. It was in effect a program of small loans implemented within a set framework of brad policies, with a series of six sub-programs that are shown in the following figure. 
Fig. 1: The New Paradigm

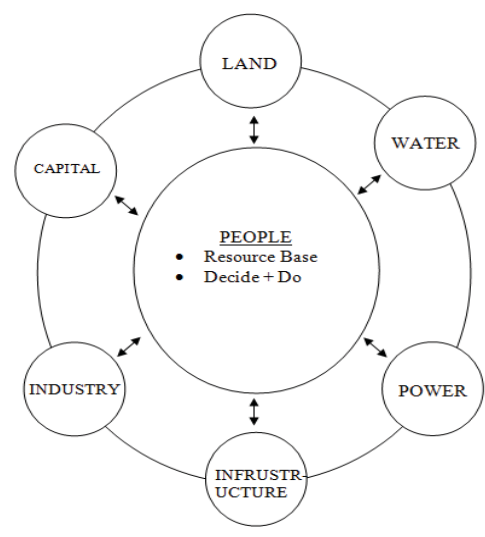

The new paradigm in the Million Houses Program required a drastic change in the Government's role. The Government was required to withdraw from the forefront of activities to the background. They wire to lend support to people engaged in the mainstream process by which they build houses for themselves. The role of the state was to support, strengthen and complement the mainstream. It would facilitate and support both individual home-builders and communities, provide plots and loans, and ease constraints, inform builders and train both participants and staff. It would intervene only when individuals and communities cannot solve problems on their own. So while the state is the supporter and facilitator, the individual families will be doers and decision-makers. It was intended that people's participation will increase and improve qualitatively and that communities will be responsible for their shelter more than ever before. The attitude to urban slums and shanties was to encourage the dwellers to upgrade their dwellings and environment situations rather than demolish houses and relocate the dwellers elsewhere.

In 1985, as part of its contribution to the International year of Shelter for the Homeless, the Building and social Housing Foundation initiated the world Habitat Awards. This Foundation is an independent non-political organization based in Britain. It concerns itself with contemporary problems of housing and with progressive and imaginative solutions that may lead to sustainable ways of life for the future. It is noteworthy that the Million Houses Program of Sri Lanka received the World Habitat Award in the year of 1987.

Recent years have seen radical changes and innovations in the delivery of shelter in Sri Lanka. The focus has shifted from costly direct construction of housing by the Government and from highly subsidized programs which reach only a limited number of households. A growing emphasis is placed on the involvement of the community and individual households in the delivery of shelter and on the use of appropriate technologies and planning standards, so that a larger number of households can be reached with the limited resources available. The role of the Government and of Local Authorities is increasingly limited to the provision of security of land tenure, basic infrastructure and securing the availability of housing finance affordable by low-income households. Training and information systems are introduced to ensure that the participatory approach is extended and institutionalized.

\section{Concluding Observation \& Recommendation}

The Million Houses Program of the Government of Sri Lanka constitutes one of the largest efforts so far to reach lowincome families in the urban and rural sector with improved infrastructure and shelter; the experience emerging from Sri Lanka provides therefore an invaluable learning process for the international community: it proves that public sector programs can be scaled up by increasingly involving beneficiaries in the delivery process through support based strategies. The extension procedures and techniques implemented in order to achieve the required decentralization of the program over the national territory constitute a model rich with useful lessons for national governments, international and bilateral agencies alike.

From the experiences of Sri Lanka it is notable that quick and participatory procedures for land registration and plot allocation, community participation techniques to promote the involvement of residents in the delivery of services, house construction and improvement, maintenance of services and overall management were tried out and produced useful tools for broader application. 
Now housing rights are determinate and justifiable. Direct arguments in support of the right to adequate housing can be founded on legally binding provisions contained in international, regional or national laws. Indeed, a better implementation of international legal texts can only represent a positive step forward. For this purpose, the establishment of an authority at the national level is in need and it should responsible for these implementations with the state guaranteeing the required resources and means for which Sri Lankan project is an example. It would require further judicial and procedural innovation at the national and international level in order to better establishment of the right to housing. housing.

The following areas are identified in which the domestic legal system could play a role in safeguarding the right to

(a) Legal appeals aimed at preventing planed evictions or demolitions through the issuance of court-ordered injunctions.

(b) Legal procedures seeking compensation following an illegal eviction.

(c) Complaints against illegal actions carried out or supported by landlord (whether public or private) in relation to rent levels dwelling maintenance, and racial or other forms of discrimination.

(d) Allegations of any form of discrimination in the allocation and availability of access to housing.

(e) Complaints against landlord concerning unhealthy or inadequate housing conditions. In some legal system it would also be appropriate to explore the possibility of facilities class action suits in situations involving significantly increased levels of homelessness.

In addition to seeking enforcement of rights by using standards directly related to the right to housing, cases can be filed using derivative claims. For example, the right to adequate housing may be implied from express guarantees of other right (e.g. the right to life, privacy of the home, right to family life) that are generally recognized as basis of civil and political rights. Indian courts have used this approach to lead the right to adequate housing into cases based on the right to life as guaranteed under article 21 of the Indian Constitution. In the case of Shanti Star Builders v. Naryan Khimali Tatome et at ., the Indian Supreme Court held as follows.

"Basic needs of man have traditionally been accepted to be free-food, Clothing and shelter. The right to life is guaranteed in any civilized society. That would take within its sweep the right to food, the right to clothing, the right to decent environment and a reasonable accommodation to live in..... For a human being [the right to shelter] has to be a suitable accommodation which would allow him to grow in every aspect-physical, mental and intellectual...... A reasonable residence is an indispensable necessity for fulfilling the constitutional goal in the matter of development of man and should be taken as included in life" in article 21.12 (Shakti Star. Builders v. Naryan Khimali Totome, SC 106, Civil Appeal No. 2598 of 1989)

Where legislation is inadequate or does not exist at all, NGOs should develop model legislation on the right to housing. Such legislation should be drafted with a view to including all minimum core components of the right the local context in mind. NGOs should then lobby for the adoption of such legislation.

Legal strategies should be combined with other strategies to ensure the full realization of the right to housing. Effective guarantees of housing rights require consultation, dialogue, negotiation and compromise rather than coercion, force, repression and exclusion. Activists must therefore acquire relevant skills for building consensus around issues relating to the right housing. Support-based strategies that recognize the role of the informal sector in the creation of housing must be developed and implemented.

In the final analysis, the full realization of the right to adequate housing would depend on the extent of awareness and action taken for ensuring its enjoyment. In fact for the implementation of adequate housing the area of slum and squatters must be focused which also needs the policies to alleviation of poverty. Regardless of past government action, in all countries there exist people who, because of personal issues such as physical or emotion incapacity, environmental issues such as natural disasters or famine, or social issues such as war or political instability, are unable to obtain housing for themselves. In those situations, governments are obligated to help make housing accessible. Governments are obligated to function as fair and stable systems through which their citizens can achieve the satisfaction of their rights, and to provide the means for the realization of the right to a decent standard of living which their citizens may utilize through their own free initiative. Policy reforms and institutional strengthening are therefore viewed as critical catalyst in the process of change unless the solution to the housing problems seems exceedingly remote. 


\section{References}

"The realization of Economic, Social and Cultural Rights," Second progress report submitted by Mr. Rajindar Sachar, Special Rapporteur. E/CN.4/Sub.2/1994/20,21 June 1994. http://www.hrea.org/index.php?doc_id=411, (July 7, 2013).

Dr. Ameen Shahidul, "Transformation practice, in low income housing", Journal of Civil Engineering. The institution of Engineers, Bangladesh, vol-26, pg no.2, 1996.

The Resolution 14/6 of United Nations Commission on Human Settlements (Habitat) (UNCHS), 5 may 1993. Aavailable:http://www.unhchr.ch/html/menu3/b/a_cescr.htm. (July 11, 2013).

United Nations General Assembly resolution 42/146, adopted on 7 December 1987, Available: http://www.un.org/Overview/rights.html. (July 7, 2013)..

Ministry of Local Government, Housing and Construction, Policy Paper, slur, and shanty upgrading in Colombo Municipal Council Colombo, 1979. Available: http://www.unhchr.ch/huridocda/huridoca.nsf/(Symbol)/E.CN.4.Sub.2.1994.20.(July 7, 2013).

Ministry of Local Government, Housing and Construction, Guidelines for implementing the Demonstration Projects program under the Million Houses Program, Colombo, 1983 and Urban shelter policy (Part 1), Low income housing, SSD/UDA, Colombo 1984,Available: http://www.unhchr.ch/huridocda/huridoca.nsf/(Symbol)/E.CN.4.Sub.2.1994.20.,, (July 7, 2013).

Ministry of Local Government, Housing and Construction, Million Houses Program, implementation guidelines, rural subprogram. (Colombo, NHDA and Department of Local Government, 1984). Available: http://www.unhchr.ch/huridocda /huridoca.nsf/(Symbol)/E.CN.4.Sub.2.1994.20.,, (July 7, 2013).

Shelter for Low-Income Communities: Sri Lanka Demonstration Project Case Study - Part I, UNCHS (Habitat), HS/80/85/E, ISBN 92-1-131029-6.

Bret Thiele, JD, "The Human Right to Adequate Housing: A Tool for Promoting and Protecting Individual and Community Health", American Journal of Public Health. 2002 May; 92(5): 712-715. 